study of pregnancy and its outcomes. Paediatr Perinat Epidemiol 2006; 20 : $148-62$.

20 Anderson JW, Johnstone BM, Remley DT. Breast-feeding and cognitive development: a meta-analysis. Am J Clin Nutr 1999; 70: 525-35.

21 Mortensen EL, Michaelsen KF, Sanders SA, Reinisch JM. The association between duration of breastfeeding and adult intelligence. JAMA 2002; 287 2365-71.

22 Horwood LJ, Fergusson DM. Breastfeeding and later cognitive and academic outcomes. Pediatrics 1998; 101: E9.

23 Richards M, Hardy R, Wadsworth ME. Long-term effects of breast-feeding in a national birth cohort: educational attainment and midlife cognitive function. Public Health Nutr 2002; 5: 631-5.

24 Caspi A, Williams B, Kim-Cohen J, Craig IW, Milne BJ, Poulton R, et al. Moderation of breastfeeding effects on the IQ by genetic variation in fatty acid metabolism. Proc Natl Acad Sci USA 2007; 104: 18860-5.

25 Renfrew MJ, Lang S, Woolridge MW. Early versus delayed initiation of breastfeeding. Cochrane Database Syst Rev 2000; 2: CD000043.

26 Gomez-Sanchiz M, Canete R, Rodero I, Baeza JE, Gonzalez JA. Influence of breast-feeding and parental intelligence on cognitive development in the 24-month-old child. Clin Pediatr 2004; 43: 753-61.

27 Angelsen NK, Vik T, Jacobsen G, Bakketeig LS. Breast feeding and cognitive development at age 1 and 5 years. Arch Dis Child 2001; 85: 183-8.
28 Jacobson SW, Jacobson JL. Breast feeding and intelligence in children. BMJ 2006; 333: 929-30.

29 Der G, Batty GD, Deary IJ. Effect of breast feeding on intelligence in children: prospective study, sibling pairs analysis, and meta-analysis. BMJ 2006; 333 945.

30 Motion S, Northstone K, Emond A, Stucke S, Golding J. Early feeding problems in children with cerebral palsy: weight and neurodevelopmental outcomes. Dev Med Child Neurol 2002; 44: 40-3.

31 McCowan LM, Pryor J, Harding JE. Perinatal predictors of neurodevelopmental outcome in small-for-gestational-age children at 18 months of age. Am J Obstet Gynecol 2002; 186: 1069-75.

32 Sisk PM, Lovelady CA, Dillard RG, Gruber KJ. Lactation counseling for mothers of very low birth weight infants: effect on maternal anxiety and infant intake of human milk. Pediatrics 2006; 117: e67-75.

33 Parer JT, Livingston EG. What is fetal distress? Am J Obstet Gynecol 1990; 162: $1421-5$.

34 Lidegaard O, Bottcher LM, Weber T. Description, evaluation and clinical decision making according to various fetal heart rate patterns. Inter-observer and regional variability. Acta Obstet Gynecol Scand 1992; 71: 48-53.

35 Morrison EH. Common peripartum emergencies. Am Fam Physician 1998; 58 1593-604.

\title{
Suspending disbelief: do we unfairly distrust our patients?
}

\section{Su Mahadevan}

As a medical student on the first day of my psychiatry attachment, I was sent to interview an in-patient with schizophrenia. I listened, innocent and enthralled, as he informed me in extensive detail how his employers had bugged his house, spiked his drinks, and recruited his neighbours to spy on him. 'But that's outrageous!' I exclaimed earnestly, 'They can't be allowed to do that. Why don't you tell the police?'

Some years on, I am pleased to say that my ability to spot the floridly psychotic and delusional patient has improved. But two recent experiences have made me question whether psychiatrists sometimes go too far in the opposite direction. A young man with personality disorder known to psychiatric services presented to accident and emergency shortly after a relationship breakdown, claiming he was unable to move his left arm and leg. On hearing of his history, psychiatric opinion sought by the acute stroke team attributed his symptoms firmly to conversion disorder, deeming further investigations both unhelpful and unnecessary. Three days later, magnetic resonance imaging revealed a large right middle cerebral artery infarct. Within a week of this experience, it came to light that an elderly patient with advanced dementia and behavioural problems, who for months had been ignored as he repeatedly talked about his carers abusing him, had in fact been describing a real situation. Discussion with experienced psychiatrists revealed that such occurrences are by no means unique or isolated.

In practice, it is easy to dismiss any unusual or improbable claim a mentally ill patient makes as untrue. Being confronted by a daily barrage of unreality - ranging from the psychotic patient with frankly bizarre delusions, to the manipulative patient intending to deceive - psychiatrists perhaps more than any other specialists are at risk of developing blanket cynicism and distrust. Elyn Saks, an American professor of law and psychiatry who herself suffered from schizophrenia, describes in her autobiographical account (The Center Cannot Hold: My Journey Through Madness; Virago, 2007) how her own subarachnoid haemorrhage was missed by experienced doctors, based on the unspoken assumption that anything a patient with a psychiatric history said was untrue. Is this attitude just another form of stigmatisation of people with mental illness?

Clearly we cannot believe everything we hear. But perhaps we should be more amenable to keeping an open mind, guarding against our own prejudices, and to investigating further in cases of uncertainty. This approach not only reduces the risk of missing a real physical or social problem, but also helps us to develop open and supportive relationships with vulnerable patients. For few things destroy trust and hope more effectively than being disbelieved when we really are telling the truth. 